\title{
AGGREGATION OF BENZENE MOLECULES WITH MOLECULES OF METHANOL AND FORMIC ACID
}

\author{
F.H. TUKHVATULLIN, A. JUMABAYEV, U.N. TASHKENBAEV, \\ H. HUSHVAKTOV, A. ABSANOV, G. SHARIFOV \\ Samarkand State University \\ (15, University Blvd., Samarkand 140104, Uzbekistan; e-mail: ngayrat@ rambler. ru)
}

PACS 78.30.-j

(C) 2012

Calculations and experimental studies of Raman scattering spectra show that there is a dimeric aggregation of benzene molecules with the molecule of methyl alcohol with the use of $\pi$-electrons of the benzene ring. In this process, the $\mathrm{H}$-active hydrogen atom of $\mathrm{O}-\mathrm{H}$ group is oriented to the edge of the benzene ring (a distance along the normal to the plane of the benzene ring is $2.850 \AA$ ). The unusual position of the $\mathrm{H}$-active hydrogen atom is conditioned by the interaction of two hydrogen atoms of the alcohol's methyl group with $\pi$-electrons of the benzene ring. In Raman scattering spectra, the aggregation of molecules in the liquid state of the substance leads to a broadening of the band of full-symmetric vibrations with the maximum at $992 \mathrm{~cm}^{-1}$, as well as to a shift of this band toward lower frequencies by $\sim 1 \mathrm{~cm}^{-1}$. The band at $992 \mathrm{~cm}^{-1}$ is narrowed more than twice at the strong dilution of the benzene-methyl alcohol mixture by a large amount of heptane. The aggregation of benzene molecules takes place also with the molecules of formic acid with the use of $\pi$-electrons of the benzene ring. As in the case of the benzene-methyl alcohol mixture, the H-active hydrogen atom of $\mathrm{O}-\mathrm{H}$ group of the acid is shifted toward the edge of the benzene ring. The energy of the benzene-formic acid dimerization is $9.2 \mathrm{~kJ} /$ mole.

\section{Introduction}

In our previous paper [1], we presented the results of studying the interaction of benzene molecules between themselves and the interaction of benzene molecules with molecules of chloroform. Calculations and experimental studies of Raman scattering spectra (RS) showed that two benzene molecules can form a dimer, by using the $\pi$-electrons of one of the rings in the process of dimerization. In this case, the planes of benzene rings are perpendicular to each other, and one of the hydrogen atoms of one benzene ring is oriented toward the center of another benzene ring. A similar pattern is realized for the dimerization of benzene and chloroform molecules. The hydrogen atom of a chloroform molecule is oriented toward the center of the benzene ring. Not all mutual orientations of the molecules are equivalent. In the benzene dimer, the proton-donor molecule is oriented so that the plane of the benzene ring passes through the diago- nal drawn through opposite carbon atoms of the proton acceptor. Moreover, two carbon atoms of the proton donor and one carbon atom of the proton acceptor are located on two parallel lines. In a chloroform-benzene dimer, the chlorine atoms are located over three carbon atoms of the proton acceptor. The resulting dimer has the axial symmetry $\mathrm{C}_{3}$. Such a mutual arrangement of atoms in the dimer is unusual. The interaction of molecules by using $\pi$-electrons was described in [2-6]. We continued to study the proton-acceptor properties of the benzene ring. In this paper, we describe the results of studying the interaction of $\pi$-electrons of the benzene ring with hydrogen atoms of the molecules of methanol and formic acid. In the solution of benzene with methyl alcohol, we investigated the Raman scattering spectra of totally symmetric vibrations with a wavenumber of $992 \mathrm{~cm}^{-1}$.

\section{Experimental Studies and Calculations}

The registration of Raman spectra was carried out with the help of an automated spectrometer DFS-52, which represents a double monochromator with two diffraction gratings 1800 lines $/ \mathrm{mm}^{-1}$. The excitation source for RS was an argon laser LGN-503 with a wavelength of 488 $\mathrm{nm}$ at the radiation power of $1 \mathrm{~W}$. All measurements were performed at the $90^{\circ}$-geometry of scattering of the polarized incident light. Accounting for the instrumental distortion, if necessary, was carried out by the method described in [7]. The measurements were performed at a temperature of $20^{\circ} \mathrm{C}$. In the experiment, we used chemically pure substances, which were subjected to the additional vacuum distillation. The error in the determination of the bandwidth and the relative position of bands was $\pm 0.3 \mathrm{~cm}^{-1}$.

Quantum chemical calculations were carried out in the RHF approximation with a set of Gaussian functions 6$31 \mathrm{G}++(\mathrm{d}, \mathrm{p})[8]$ for the isolated monomeric molecules of methanol and formic acid, for a dimer aggregate of 


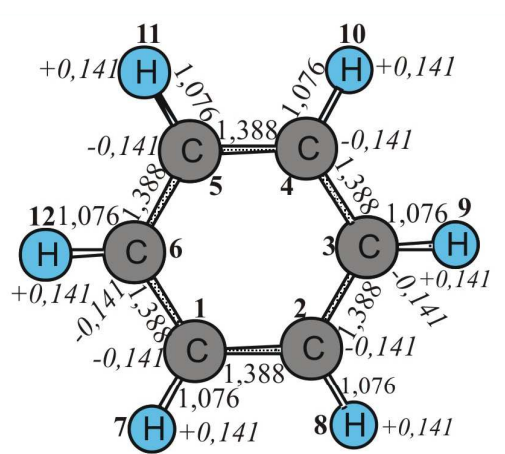

$a$

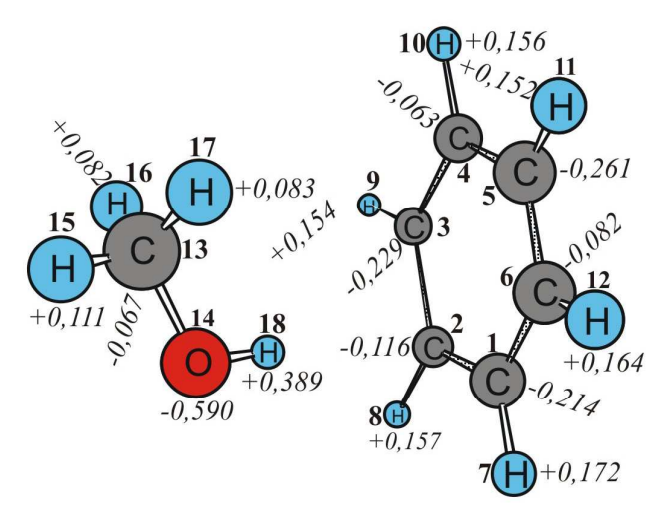

$d$
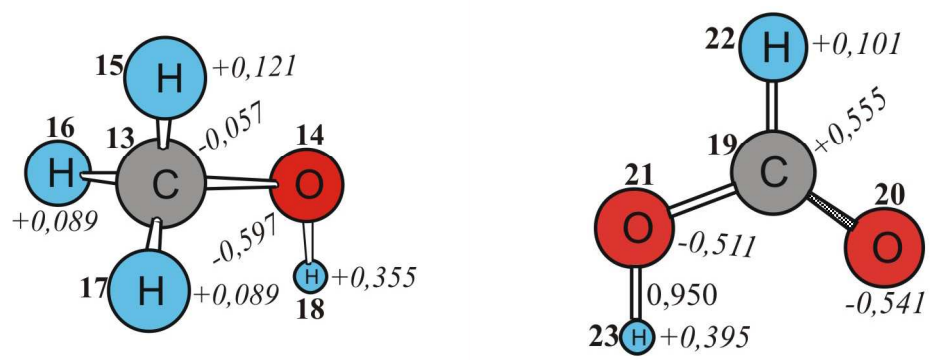

$b$

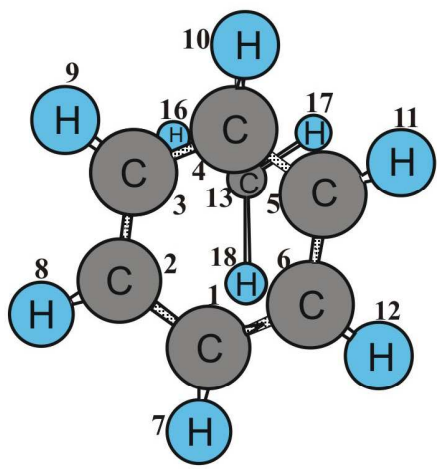

e

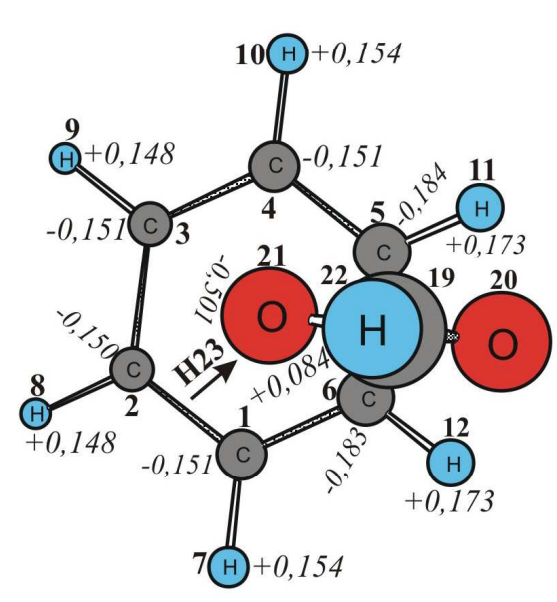

$f$

Calculated structure of a benzene monomer $(a)$, methanol $(b)$, formic acid $(c)$ and dimeric aggregates of methyl alcohol-benzene $(d-$ side view, $e$ - top view) and formic acid-benzene ( $f$ - top view, distances in $\AA$, charges in units of electron charge)

benzene and methyl alcohol, and for a benzene-formic acid dimer aggregate.

\section{Discussion}

Let us discuss, first of all, the results of quantum chemical calculations of the interaction of molecules of methyl alcohol and benzene among themselves in an isolated aggregate. As in the case of chloroform, $\pi$-electrons of the benzene ring interact with the hydrogen atom of the O-H group of alcohol. But it has its own peculiarities. This hydrogen atom is oriented not just toward the center of a benzene ring, as it was in the case of a dimer of benzene and chloroform, but it is shifted to the edge of the benzene ring (see Figure) and is located near the carbon atoms $\mathrm{C}^{1} \mathrm{C}^{2} \mathrm{C}^{6}$ (distances of $\mathrm{H}^{18} \mathrm{C}^{1}, \mathrm{H}^{18} \mathrm{C}^{2}$ and $\mathrm{H}^{18} \mathrm{C}^{6}$ are equal, respectively, to $2.889,3.171$, and $3.029 \AA$; but those of $\mathrm{H}^{18} \mathrm{C}^{3}, \mathrm{H}^{18} \mathrm{C}^{4}$ and $\mathrm{H}^{18} \mathrm{C}^{5}$ are equal, respectively, to $3.549,3.664$, and $3.428 \AA$ (numbers of atoms are the same as in Figure). What is the reason for such a displacement of $\mathrm{H}^{18}$ atom to the edge of the benzene ring? This is probably due to the interaction of the hydrogen atoms of alcohol $\mathrm{H}^{16}$ and $\mathrm{H}^{17}$ (charges, respectively, +0.082 and +0.083 electronic units are less as compared with charges of the same atoms in the monomer molecule which are 0.089 and 0.089 , respectively) with atoms $\mathrm{C}^{3}$ and $\mathrm{C}^{5}$, respectively, whose negative charges are increased in comparison with that in a monomer molecule (in the monomer, they are -0.143 and -0.143 ; in the aggregate, they are -0.229 and -0.261 , respectively). The third hydrogen atom of the methyl group $\mathrm{CH}_{3} \mathrm{C}^{15}$ does not participate in the $\pi$-electron bonding, but it is involved in the intramolecular hydrogen bonding: the length of the bond $\mathrm{H}^{15} \mathrm{O}^{14}$ is $2.067 \AA$. Thus, the hydrogen atom $\mathrm{H}^{18}$ is shifted to the edge of the benzene ring due to the fact that three hydrogen 
atoms $\mathrm{H}^{17}, \mathrm{H}^{16}$, and $\mathrm{H}^{18}$ of the molecule of methyl alcohol participate in the interaction with $\pi$-electrons of the benzene ring. Such mutual orientation of benzene and methyl alcohol seems to be energetically favorable. The distance along the normal to the plane of the benzene ring for $\mathrm{H}^{18}$ is $2.850 \AA$. The distance of $\mathrm{H}^{16}-\mathrm{C}^{3}$ is $4.143 \AA$, and that of $\mathrm{H}^{17}-\mathrm{C}^{5}$ is $4.142 \AA$.

In Raman spectra, the band with peak at $992 \mathrm{~cm}^{-1}$ for pure benzene has a half-width of $2.3 \mathrm{~cm}^{-1}$. This band should be broadened due to the presence of monomer molecules and dimeric aggregates of benzene molecules in the liquid benzene. The frequency of vibrations of the monomer molecules of benzene, according to calculations, only slightly differs from the frequency of vibrations of the dimer by $\sim 0.7-0.2 \mathrm{~cm}^{-1}$. Of course, the spectral apparatus cannot resolve these lines. The effect is manifested only in increasing the line width. The strong dilution of benzene with an inert solvent (heptane) leads to a narrowing of this band by almost two times, which, in our view, is partially connected with the collapse of the dimeric aggregates. The dilution of benzene by a large amount of methanol does not lead to a large change in the line width $\left(1.8 \mathrm{~cm}^{-1}\right)$. This effect can be explained: in a mixture of benzene and methyl alcohol, the dimers of benzene are replaced by benzene-alcohol dimers with almost the same difference between the wavenumbers of monomers and dimers of benzene and alcohol, and with the same direction of the band's shift, as in the case of a benzene dimer. However, at a high dilution of the mixture with a neutral solvent (heptane), there is the narrowing of the $992-\mathrm{cm}^{-1}$ band by almost two times, as this was in the case of benzene. Simultaneously, the band is shifted toward higher frequencies by $1 \mathrm{~cm}^{-1}$. The explanation is the same as for benzene: the benzene-methyl alcohol dimers are destroyed, and we are dealing only with the monomer molecules of benzene in the mixture. Calculations show that the energy of the hydrogen bond methyl alcoholbenzene is $6.5 \mathrm{~kJ} / \mathrm{mol}$. In Raman spectra, the benzene band at $1075.4 \mathrm{~cm}^{-1}$ (experiment gives $992 \mathrm{~cm}^{-1}$ ), according to calculations, in the mixture with the alcohol shifts toward the low-frequency region $\left(1074.3 \mathrm{~cm}^{-1}\right)$. The difference is of $1.1 \mathrm{~cm}^{-1}$, and the spectral apparatus cannot resolve the lines of monomers and aggregates, the band is just broadened. The $\mathrm{O}-\mathrm{H}$ band of alcohol under the aggregation with benzene should also shift toward the low-frequency region (the calculated wavenumber of a monomer is $4196.4 \mathrm{~cm}^{-1}$, and that of the aggregate is $4182 \mathrm{~cm}^{-1}$; due to the approximate nature of the calculation method, the exact coincidence of the values of the vibrational frequencies with experimental values is achieved by introducing a scaling factor. In our case, the scaling factor is 0.92 ).

We have also calculated the interaction of formic acid molecules with benzene molecules. Figure $(e)$ shows an aggregate of formic acid - benzene. As in the previous cases, the interaction of molecules occurs with the use of $\pi$-electrons of the benzene ring, but here, as in the case of methanol, there are peculiarities. The hydrogen atom of $\mathrm{O}-\mathrm{H}$ group of acid is oriented into the benzene ring, but not to the center. This can be judged from the distances of $\mathrm{H}^{23}$ atom to the carbon atoms of benzene: $\mathrm{H}^{23}-\mathrm{C}^{1}-3.281 \AA, \mathrm{H}^{23}-\mathrm{C}^{2}-3.728 \AA, \mathrm{H}^{23}-\mathrm{C}^{3}-$ $3.729 \AA, \mathrm{H}^{23}-\mathrm{C}^{4}-3.282 \AA, \mathrm{H}^{23}-\mathrm{C}^{5}-2.762 \AA, \mathrm{H}^{23}-$ $\mathrm{C}^{6}-2.762 \AA$. It turns out that the hydrogen atom $\mathrm{H}^{23}$ is located on the edge of the benzene ring at equal distances from the atoms $\mathrm{C}^{5}$ and $\mathrm{C}^{6}$. The reason for this orientation of $\mathrm{H}^{23}$, in our opinion, is as follows: carbon atom of acid is positively charged $(+0.555$ in the monomer) and it also interacts with the $\pi$-electrons of the ring (negative charge). Bond $\mathrm{C}^{5}-\mathrm{C}^{6}$ of benzene passes between the oxygen atoms of $-\mathrm{C}=\mathrm{O}$ acid. Apparently, this arrangement of the molecules is most energetically favorable. Thus, there is no necessity for a hydrogen atom to participate only in the interaction. Under suitable conditions, the interaction may involve other atoms. Note that the length of $\mathrm{C}^{5} \mathrm{C}^{6}$ is a little longer $(1.3896 \AA)$ than that of other intercarbon bonds $(1.3882 \AA)$. Charges of atoms $\mathrm{C}^{5}$ and $\mathrm{C}^{6}$ (negative) is somewhat larger $(-0.183)$ than charges of other carbon atoms of the ring $(-0.150)$, although these charges are a little greater than the charges of the monomer molecules of benzene. The charges of atoms of formic acid are also changed. The charge of the carbon atom of acid is increased as a result of the interaction (up to +0.561 , in the monomer +0.555$)$. The charge of the hydrogen atom of O-H group is slightly increased $(+0.411$ in the dimer, and +0.395 in the monomer; in case of the usual hydrogen bond, the charge of this atom usually increases considerably). The negative charges of oxygen atoms are redistributed $\left(\mathrm{O}^{21}-0.501, \mathrm{O}^{20}-0.535\right.$; in the monomer 0.541 and 0.501 , respectively). The positive charge of the hydrogen atom $\mathrm{H}^{22}$ is decreased $(+0.084$, and +0.101 in the monomer). How the interaction of formic acid with benzene should be manifested in Raman spectra? The full-symmetric band at $992 \mathrm{~cm}^{-1}$ typical of benzene (calculation gives $1075.4 \mathrm{~cm}^{-1}$ ) is shifted toward lower frequencies by $1.5 \mathrm{~cm}^{-1}$. $\mathrm{O}-\mathrm{H}$ band of formic acid should undergo a low-frequency shift by $46.6 \mathrm{~cm}^{-1}$. The change in the Raman spectrum is fairly large and corresponds to 
a significant energy gain of $9.2 \mathrm{~kJ} / \mathrm{mol}$ in the formation of the formic acid - benzene aggregate.

As in [1], the calculations presented in this paper are related to the isolated formations of benzene - methyl alcohol and benzene - formic acid. Features of the liquid state are not taken into account. In the calculations, as seen from the above, we do not consider the interaction of aggregates with the environment and the thermal motion of molecules. The tendency of changes in molecular values should, however, be preserved in the transition to solutions.

The interaction of molecules and the formation of aggregates with the participation of $\pi$-electrons of benzene in a number of properties is different from an ordinary hydrogen bond. To fully understand this kind of interaction, further studies are needed.

1. F.H. Tukhvatullin, A. Jumabaev, H. Hushvaktov, A. Absanov, and G. Sharifov, J. Acad. Scien. of Uzbekistan (in press).

2. K.C. Janda, J.C. Hemminger, J.S. Winn, S.E. Novick, S.J. Harris, and W.J. Klemperer, J. Chem. Phys. 63, 1419 (1975).

3. P. Hobza, H.L. Selzle, and E.W. Schlag, Chem. Rev. 94, 1767 (1994).

4. C. Gonzalex and E.C. Lim, J. Chem. Phys. 104, 2953 (2000).

5. Y. Zhao and D.G. Truhlar, J. Chem. Phys. 109, 4209 (2005).

6. P. Hobza and Z. Havlas, Chem. Rev. 100, 4253 (2000).
7. K. Tanabe and J. Hiraichi, Spectrochim. Acta. 36A, 341 (1980).

8. M.J. Frisch, G.W. Trucks, and H.B. Schlegel, Gaussian 98 (Gaussian, Pittsburgh, 1998).

Received 23.09.11

\section{АГРЕГАЦІЯ МОЛЕКУЛ БЕНЗОЛУ 3 МОЛЕКУЛАМИ МЕТАНОЛУ І МУРАШИНОЇ КИСЛОТИ}

Ф.Х. Тухватуллін, А. Джумабаєв, У.Н. Ташкенбаєв, Х. Хуштактов, А. Абсанов, Г. Шаріфов

Р е з ю м е

Розрахунок і експериментальні дослідження спектрів раманівського розсіяння показали, що відбувається димерна агрегація молекул бензолу з молекулами метилового спирту за участю $\pi$-електронів бензольного кільця. У цьому процесі активний атом водню О-Н групи орієнтований до краю бензольного кільця (відстань вздовж нормалі до площини бензольного кільця дорівнює $2,850 \AA$ А̊). Незвичне положення активного атома водню зумовлено взаємодією двох атомів водню метилової групи спирту з $\pi$-електронами бензольного кільця. Агрегація молекул рідини приводить у спектрах раманівського розсіяння до уширення смуги повносиметричних коливань з максимумом при $992 \mathrm{~cm}^{-1} \mathrm{i}$ до зсуву цієї смуги у бік менших частот на $\sim 1 \mathrm{~cm}^{-1}$. Смуга при $992 \mathrm{~cm}^{-1}$ вужчає більше ніж вдвічі при сильному розбавленні суміші бензол-метанол значною кількістю гептану. Молекули бензолу також агрегують з молекулами мурашиної кислоти за участю $\pi$-електронів бензольного кільця. Як і для суміші бензол-метанол, активний атом водню О-Н групи кислоти зміщується до краю бензольного кільця. Енергія димеризації бензолу з молекулою мурашиної кислоти дорівнює 9,2 кДж/моль. 